\title{
THE EFFECTIVENESS OF "FATIMA" TO REDUCE STRESS IN POSTPARTUM MOTHERS: A COPING STRATEGY DURING COVID-19 PANDEMIC
}

\author{
Ika Sumiyarsi Sukamto, Siti Nurhidayati, Niken Bayu Argaheni, \\ Luluk Fajria Maulida, Nurul Jannatul Wahidah, \\ Inas Azhar Dwi Haryadi
}

Midwifery Study Program, Faculty of Medicine, Universitas Sebelas Maret

\begin{abstract}
Background: During COVID-19 pandemic postpartum mothers face higher risk of experiencing stress. Progressive education, diaphragmatic relaxation, and music are interventions that can be done to reduce stress levels in postpartum mothers. This study aimed to analyze the effect of FATIMA management on lowering stress levels in postpartum mothers during the COVID-19 pandemic.

Subjects and method: This was a quasi-experiment study with pre-post test one group design, conducted in Yogyakarta Community Health Center from July to August 2021. A total of 40 postpartum mothers was selected by total sampling. The dependent variable was stress level. The independent variable was "FATIMA" intervention. FATIMA's intervention was performed for 28 days including educational videos, diaphragm relaxation and music. Stress levels was measured by Perceived Stress Scale (PSS) and analyzed by ttest.

Results: Stress level after FATIMA's intervention (Mean= 25.20; SD= 7.14) was lower than before (Mean=30.50; $\mathrm{SD}=7.37)$ and it was statistically significant $(\mathrm{p}<0.001)$.

Conclusion: The FATIMA intervention is effective in reducing stress in postpartum mothers.

Keywords: postpartum mothers, stress, FATIMA management, relaxation, COVID-19

\section{Correspondence:}

Ika Sumiyarsi Sukamto. Midwifery Study Program, Faculty of Medicine, Universitas Sebelas Maret, Surakarta, Indonesia. Jl. Ir. Sutami 36A, Surakarta 57126, Central Java. Email: ikasumiyarsi@staff.uns.ac.id. Mobile: +6281548515239.
\end{abstract}

